\title{
Equities Incentive, Informativeness of Stock Price and Earnings Management: Based on the Chinese A-Share Listed Companies
}

\author{
Qifan Zhong \\ School of Economics, Jinan University, Guangzhou, China \\ Email: fun.compsition@gmail.com
}

Received 23 February 2016; accepted 19 March 2016; published 22 March 2016

Copyright (C) 2016 by author and Scientific Research Publishing Inc.

This work is licensed under the Creative Commons Attribution International License (CC BY).

http://creativecommons.org/licenses/by/4.0/

c) (i) Open Access

\begin{abstract}
Equities incentive is more and more frequently used for motivating management among Chinese listed companies, but whether it will degrade informativeness of stock price, thus reduce the efficiency of capital allocation in security market remains to be verified. This article used the data of A-share listed companies in China from 2010-2014, deployed an empirical research to study the relationship between equities incentive and informativeness of stock price, considering earnings management as an intermediary variable. According to the analysis results, we found that higher level of equities incentive tended to degrade the level of informativeness of stock price, and the earnings management was not an effective intermediary variable, which meant the earnings management resulted from equities incentive was less likely to affect informativeness of stock price.
\end{abstract}

Keywords

Equities Incentive, Informativeness of Stock Price, Earnings Management

\section{Introduction}

The financial market is the core pillar of financial system, with the trader in financing institution or securities exchanges frequently exchanging currency, capital and stock with each other; resources within a society can be deployed in a more suitable place efficiently, which greatly helps to ensure the economy of a country to develop in a sustainable and well-organized way. Security market is the most important and active proportion of the financial market. Company can acquire the capital necessary for further developing by directly issuing stocks in security market; the highly liquid stocks can be easily exchanged in exchanges, making the security market the 
most powerful and efficient instrument for directing capital. Therefore, many people are focusing on how to improve the efficiency of the security market.

The extent of ability of a security market to direct capital largely depends on whether it can provide right signal, which mostly contains in stock price, to lead investors to put their money in right place. Therefore, the extent of informativeness of stock price, which indicates the real condition of an individual company, largely determines the efficiency of security market. Roll [1] came up with a method to measure the informativeness of stock price in 1988 and his method was considered the most important measuring method of stock price information nowadays. Wurgler [2] and Chen, Goldstein, Jiang [3] had done some empirical research; the results confirmed the positive correlation between informativeness of stock price and efficiency of security market. Currently, more and more people are trying to figure out the factors that affect informativeness of stock price. One of the factors, which continues to attract attention, is the equities incentive paid to the management.

Currently, more and more Chinese public companies issue equities incentive plans to motivate management for their better effort in improving business condition. Since equities incentive for management is generally considered as an important factor that stimulates management to deploy earnings management, which misleads investors and results in lower informativeness of stock price; how equities incentive will affect informativeness of stock price, especially how the earnings management resulted from equities incentive will degrade informativeness of stock price, remains to be a topic for further discussion.

Under the environment that many Chinese companies begin to take equities incentive plan as a tool to ensure better development, figuring out how these plans will directly affect stock price information, or indirectly affect it through the relation between them and earnings management will help public companies make their decisions towards incentive plan correctly. As there are still few empirical researches providing evidence for this topic, this article bases on Roll's method for measuring stock price information and Jones [4] model for measuring earnings management, and uses 893 Chinese A-share listed public company's data to explore how equities incentive will directly or indirectly affect informativeness of stock price when earnings management is considered as an intermediary variable.

\section{Literature Review}

Since foreign security market already had a longer history of development, the foreign public companies tried to use equities incentive as a motivation tool much earlier than Chinese companies. There were a number of foreign researches of the relationship between equities incentive and earnings management. After studying the data from 1992 to 1999 of 1500 companies tracked by S \& P, Gao and Shrieve [5] find that a positive relation is clearly shown between the ratio and value of the stock held by management and the extent of earnings management. Wei [6] studied 30,000 stock option execution events from 2741 American companies and reached a conclusion that the extent of earnings management will increase dramatically when the execute day was near. However, other researchers made different conclusions by using different method and data. Armstrong, Jagolinzer and Larcker [7] deployed an empirical research on the data of 4051 companies from 2001 to 2005 and find that the CEO incentive plan actually reduces the frequency of accounting discrepancies. Erickson, Michelle and Edward [8] studied the condition of 50 companies who was accused for their accounting discrepancies between 1996 and 2003, only finding there was no significant relationship between equities incentive and financial fraud.

Similar contradiction also happens in researches towards Chinese companies. Zhao Xi et al. [9], Lin Dapang [10] and several other researchers' results showed that the incentive plan will stimulate management to deploy earnings management, while other researchers, such as Chen Qianli [11], Tian Cunzhi et al. [12], reach a conclusion of the incentive plan will not necessary degrade financial report quality, or even can improve the governance of a company.

Though Roll has put forward his measuring method of informativeness of stock price in 1988 and more and more researchers were interested in finding the factor affecting the informativeness, the empirical research towards how equities incentive and earnings management affect informativeness of stock price was still few, especially the research in China. The existing researches also gave out some contradictive results, Yuan Zhizhu et al. [13], Zhu Yuqiao [14]'s researches showed that the equities incentive could increase the information in stock price, while Zhang Yimin [15]'s research showed that the results of incentive plans would probably degrade the informativeness of stock price, especially when the size of company was large. The researches of how earnings management affected informativeness of stock price also gave out two different results, Lu Yao et al. [16], 
Liang Quanxi [17]'s studies concluded that earnings management would increase the stock price synchronicity, thus degrade the informativeness of stock price. However, Xia Fang [18]'s research showed that the earnings management actually reduced the sample companies' stock price synchronicity, which indicated that the stock price include more information of individual company.

Based on the literature review, the relationship between equities incentive and informativeness of stock price was uncertain due to the researchers used different method and data from different companies and period, same condition also happened to the relation between earnings management and informativeness of stock price. Besides, most existing researches towards Chinese companies of this topic used data earlier than 2010.

To further confirm the relationship between equities incentive and informativeness of stock price as well as the mechanism causing the influence, this article uses the data from 2010 to 2014 of 893 Chinese public companies, trying to figure out the current relationship between equities incentive and informativeness of stock price. The innovations of this article are as follows: 1) this article uses recent data of listed companies in China to confirm whether the influence of equities incentive to informativeness of stock price still exists and the consequences of the influence; 2) using earnings management to reflect the effects of equities incentive to corporate governance, this article try to figure out whether the influence of equities incentive to corporate governance will indirectly affect the relationship of equities incentive and informativeness of stock price by taking earnings management as an intermediary variable.

\section{Research Design}

\subsection{Research Hypothesis}

Based on existing researches and analysis, the equities incentive makes management's profit directly links to the performance of company stock, which gives them strong motivation to deliberately intervene stock price through different ways, such as issuing false information, earnings management or other methods that can manipulate stock price. These efforts lead to stock price is not representing the real condition of a company, thus degrade in informativeness. Therefore, we put forward the following hypothesis:

- Hypothesis 1: Higher level of equities incentive will lead to more earnings management;

- Hypothesis 2: Higher level of equities incentive will degrade the informativeness of a company's stock price;

- Hypothesis 3: Earnings management is an effective intermediary variable in the relationship between equities incentive and informativeness of stock price, which means the earnings management results from equities incentive will effectively degrade the informativeness of stock price.

\subsection{Sample Illustration}

This article based on the data of all Chinese A-share public companies without following conditions: 1) companies in financial industry; 2) companies listed less than 5 years till 2014; 3) delisted companies; 4) companies' amount of liquid shares do not reach $50 \%$ of entire equity; 5) stock tradable days less than 1125 days within 2010 to 2014 ; 6) stock average daily turnover rate more than $15 \%$ within 2010 to 2014 .

After filtering A-share listed companies, we receive a sample with 893 companies. In this article, the data used to calculate informativeness of stock price and the data of control variables is collected from CSMAR database, while the data of earnings management and equities incentive is collected from Wind database. The data processing uses EViews 8.0.

\subsection{Empirical Model and Variables}

\subsubsection{Variables Illustration}

This article's analysis based on following variables:

\section{The Measurement of Informativeness of Stock Price $\left(\right.$ Info $\left._{i, t}\right)$}

We use Roll's measuring method to measure sample companies' informativeness of stock price. Roll considered individual company's stock investment yield $\left(r_{i, t}\right)$ can be represented by market yield $\left(r_{m, t}\right)$ and industry yield $\left(r_{j, t}\right)$, their relation can be presented as:

$$
r_{i, t}=\beta_{i, 0}+\beta_{i, m} \cdot r_{m, t}+\beta_{i, j} \cdot r_{j, t}+\varepsilon_{i, t}
$$

If we use $R_{i}^{2}$ to represent the coefficient of determination of the above regression model, Roll's research 
shows that $\left(1-R_{i}^{2}\right)$ is a good representation of a stock's asynchronization, which means the fluctuation of stock price other than the effect of industry and market. Roll consider these asynchronization shows the information of an individual company, thus reflect the extent of informativeness of a stock's price.

As the value of $\left(1-R_{i}^{2}\right)$ only limited within $[0,1]$, which is not optimized for further empirical study, we make logarithmic transformation of the value as follows:

$$
\text { Info }_{i, t}=\log \left(\frac{R_{i}^{2}}{1-R_{i}^{2}}\right)
$$

As shown above, higher value in Info shows the higher level of synchronization in company stock yield and market yield as well as industry yield, thus means the stock price contains less individual company's information.

\section{The Measurement of Equities Incentive (Incent $t_{i, t}$ )}

Currently, there are many ways to measure the extent of equities incentive for management, this article uses the ratio of share held by management (Share-Manage ${ }_{i, t}$ ) to entire equity (Share-All $l_{i, t}$ ) as a measurement of equities incentive, it can be calculated as:

$$
\text { Incent }_{i, t}=\text { Share-Manage }_{i, t} / \text { Share-All }_{i, t}
$$

\section{The Measurement of Earnings Management $\left(D A_{i, t}\right)$}

According to Healy [19]'s definition of earnings management, which is one of the most widely used definition, earnings management is management authorities based on the intention to maximize their self-interest, manipulates the accounting policy or financial statement which should be provided in line with accounting standard, in order to mislead the investors or stakeholders reach incorrect conclusion on company's condition and make inappropriate decision. One of the most widely used measurement of earnings management is Jones model.

This article uses the modified Jones model to evaluate the earnings management of companies. Jones used the ratio of discretionary accruals to total assets $\left(D A_{i, t}\right)$ as the estimate value for the extent a company deploys earnings management in his model.

First, Jones divides total accruals $\left(T A C C_{i, t}\right)$ into discretionary accruals $\left(D A C C_{i, t}\right)$ and non-discretionary accruals $\left(N D A C C_{i, t}\right)$. The total accruals can be calculated as:

$$
T A C C_{i, t}=\text { Net Income of Year } t\left(N I_{i, t}\right) \text {-Operating Cash Flow of Year } t\left(O C F_{i, t}\right)
$$

Second, Jones collects the total asset of company $\mathrm{i}$ in year $\mathrm{t}\left(T A_{i, t}\right)$, changes of total revenue in year $t$ (GRE$\left.V_{i, t}\right)$, changes of receivables in year $t\left(G R E C_{i, t}\right)$ and total fixed assets in year $t\left(P P E_{i, t}\right)$, and uses least square method to estimate the coefficient $\beta_{1}, \beta_{2}$ and $\beta_{3}$ in following regression model:

$$
\frac{T A C C_{i, t}}{T A_{i, t-1}}=\beta_{1} \times \frac{1}{T A_{i, t-1}}+\beta_{2} \times \frac{G R E V_{i, t}-G R E C_{i, t}}{T A_{i, t-1}}+\beta_{3} \times \frac{P P E_{i, t}}{T A_{i, t-1}}+\mu_{i, t}
$$

Third, Jones puts the estimated $\beta_{1}, \beta_{2}$ and $\beta_{3}$ from above model into following equation and calculates the ratio of non-discretionary accruals to total assets $\left(N D A_{i, t}\right)$ :

$$
N D A_{i, t}=\frac{N D A C C_{i, t}}{T A_{i, t-1}}=\hat{\beta}_{1} \times \frac{1}{T A_{i, t-1}}+\hat{\beta}_{2} \times \frac{G R E V_{i, t}-G R E C_{i, t}}{T A_{i, t-1}}+\hat{\beta}_{3} \times \frac{P P E_{i, t}}{T A_{i, t-1}}
$$

Finally, Jones puts the estimated $N D A_{i, t}$ into following equation to calculate $D A_{i, t}$. The ratio of discretionary accruals to total assets can be positive and negative according to the actual earnings management condition of the company, but this article aims at analyzing the extent of earnings management, so we just pay attention to the absolute value of $D A_{i, t}$ :

$$
D A_{i, t}=\left|\frac{T A C C_{i, t}}{T A_{i, t-1}}-N D A_{i, t}\right|
$$

\section{Control Variable Illustration}

According to the existing research results, we choose following control variables: 
1) Dummy variable of if chairman also works as CEO $\left(\right.$ Chairman $\left._{i, t}\right)$ : if the chairman of board of director also works as the company's CEO, it may affect the independence and effectiveness of board of director. This control variable will be value as 1 if the chairman works as CEO;

2) Ratio of independent directors in board of director (Indep_director ${ }_{i, t}$ );

3) The size of the company $\left(\operatorname{Size}_{i, t}\right)$ : this article use natural logarithm of company total assets as measurement of company size;

4) Dummy variable of if being audited by Big4 accounting firm $\left(\right.$ Accfirm $\left._{i, t}\right)$ : if the financial statement of the company is audited by Big4 accounting firm (including PWC, Deloitte, E \& Y and KPMG), this variable will be valued as 1;

5) Dummy variable of audit opinion $\left(\mathrm{Audit}_{i, t}\right)$ : if the auditing firm issue a standard and unqualified report of company $i$ in year $t$, this variable will be valued as 1 ;

6) The financial leverage (Leverage $e_{i, t}$ ): calculated as the ratio of total liability to total asset;

7) The ratio of book value to market value of a company $\left(B t o M_{i, t}\right)$ : used to represent growth of a company in the future;

8) The fluctuation of industry yield (Var-indyld ${ }_{i, t}$ ): according to the industry classification standard of China Securities Regulatory Commission, this article divides all listed companies into 18 groups and calculate the yearly variance of each group stocks' value-weighted average weekly yield;

9) This article also deploys industry dummy variables to control the effect of industry. According to the latest industry classification standard of China Securities Regulatory Commission, we divide sample companies into 16 industry groups and set 15 industry dummy variables.

\subsubsection{Empirical Model Illustration}

This article's analysis is based on the intermediary variable model, which has been proved to be effective in analysis whether the indirect influence is found between two factors. We analyze the relation between equities incentive and informativeness of stock price using following models:

Model 1: to verify the relation between equities incentive and earnings management:

$$
\begin{aligned}
D A_{i, t}= & \alpha_{1}+\alpha_{2} \times \text { Incent }_{i, t}+\alpha_{3} \times \text { Chairman }_{i, t}+\alpha_{4} \times \text { Indep_director }_{i, t}+\alpha_{5} \times \text { Size }_{i, t}+\alpha_{6} \\
& \times \text { Accfirm }_{i, t}+\alpha_{7} \times \text { Audit }_{i, t}+\mu_{1}
\end{aligned}
$$

Model 2: to verify the relation between equities incentive and informativeness of stock price:

$$
\text { Info }_{i, t}=\beta_{1}+\beta_{2} \times \text { Incent }_{i, t}+\beta_{3} \times \text { Leverage }_{i, t}+\beta_{4} \times \text { BtoM }_{i, t}+\beta_{5} \times \operatorname{Var}_{\text {-indyld }}+\beta_{6} \times \text { Size }_{i, t}+\mu_{2}
$$

Model 3: to verify whether earnings management results from equities incentive will affect the informativeness of stock price:

$$
\text { Info }_{i, t}=\theta_{1}+\theta_{2} \times \text { Incent }_{i, t}+\theta_{3} \times D A_{i, t}+\theta_{4} \times \text { Leverage }_{i, t}+\theta_{5} \times \text { Bto }_{i, t}+\theta_{6} \times \text { Var-indyld }_{i, t}+\theta_{7} \times \text { Size }_{i, t}+\mu_{2}
$$

Based on above models, if the coefficient $\alpha_{2}$ and $\theta_{3}$ are both negative, then this result indicates that earnings management is not an effective intermediary variable for the relationship between equities incentive and informativeness of stock price. On the contrary, if those both are positive, then this result indicates that earnings management performs a fully intermediary effect in how equities incentive affects informativeness of stock price. If $\alpha_{2}, \beta_{2}, \theta_{2}$ and $\theta_{3}$ are both proved to be positive in the model, then this result indicates that earnings management only performs partial intermediary effect in how equities incentive affects informativeness of stock price.

\subsection{Descriptive Statistics}

Table 1 shows the mean value of Info is relatively low and negative, indicates the sample companies' stock yield tend to be asynchronous with market yield and industry yield, which is a sign of relatively high informativeness. The standard deviation of Info is also relatively low, indicates that most of the sample companies' stock price fluctuation tends to represent individual company information. The mean value of incent is high at 0.5823 , indicates the average proportion of shares held by the management in sample companies is $58.23 \%$. The mean value of DA is low at only 0.0744 , but the standard deviation is relatively high, indicates that though the 
Table 1. Descriptive statistics of variables.

\begin{tabular}{ccccccc}
\hline Variables & Sample Size & Mean Value & Standard Deviation & Median & Maximum & Minimum \\
\hline Info & 4465 & -0.2689 & 0.3804 & -0.2214 & 0.8117 & -3.0857 \\
Incent & 4465 & 0.5823 & 0.4399 & 0.8361 & 1.0000 & 0.0000 \\
DA & 4465 & 0.0744 & 0.1625 & 0.0467 & 7.6655 & 0.0000 \\
Chairman & 4465 & 0.1536 & 0.3606 & 0.0000 & 1.0000 & 0.0000 \\
Indep_Director & 4465 & 0.3660 & 0.0553 & 0.3333 & 0.6667 & 0.0000 \\
Size & 4465 & 5.5781 & 0.5449 & 5.5288 & 8.1408 & 3.1743 \\
Accfirm & 4465 & 0.0616 & 0.2404 & 0.0000 & 1.0000 & 0.0000 \\
Audit & 4465 & 0.9691 & 0.1731 & 1.0000 & 1.0000 & 0.0000 \\
Leverage & 4465 & 0.5118 & 0.2251 & 0.5175 & 6.2808 & 0.0071 \\
BtoM & 4465 & 1.1840 & 1.0722 & 0.8550 & 8.8635 & 0.0000 \\
Var-Indyld & 4465 & 0.0010 & 0.0004 & 0.0009 & 0.0082 & 0.0004 \\
\hline
\end{tabular}

extent of earnings management in sample companies is generally low, the actual condition tend to vary across companies.

\subsection{Correlation Analysis}

Table 2 shows the Pearson correlation analysis results for variables. Most of the correlation value is low, only the Size, BtoM and Leverage show relatively high correlation level. These three factors do have some theoretical relation with each other, as larger company tend to use debt financing instrument more and some large Chinese companies, especially the companies that provide necessary services in daily life such as telecommunication, transport and energy, tend to underperform in stock price when compared with their business performance and asset scale. However, they represent different aspect of a company and many researches use them in combine with each other. Therefore, we suggest that there is no serious multiple correlation between variables.

\section{Empirical Analysis}

Table 3 shows the results of empirical analysis of three models. The F-value test results indicate that all models are statistically significant.

In model 1, the coefficient of Incent is only positive at the significance level of $10 \%$ and the value is positive at 0.0098 , indicates the relation between equities incentive and earnings management among sample companies is relatively weak, but higher level of incentive will still increase the extent of earnings management. This result verifies Hypothesis 1.

In model 2, the coefficient of Incent is positive at the significance level of 5\% and the value is positive at 0.0464, indicates higher level of equities incentive will increase the synchronization of individual company's stock yield and market yield as well as industry, thus degrade the informativeness of stock price. This result verifies Hypothesis 2.

In model 3, the coefficient of Incent is positive at the significance level of 5\% but the coefficient of DA is negative given all the significance levels. Besides, the value of coefficient of Incent only changes marginal comparing with model 2 , indicates that earnings management is not an effective intermediary variable for the relation between equities incentive and informativeness of stock price. The equities incentive can directly affect both earnings management and informativeness of stock price, but the earnings management results from equities incentive does not have a strong relationship with informativeness of stock price. Hypothesis 3 is denied according to the result of model 3.

\section{Conclusions and Limitations}

This article studies the relationship between equities incentive for management in Chinese public companies and 
Table 2. Pearson correlation coefficients for variables.

\begin{tabular}{|c|c|c|c|c|c|c|c|c|c|c|}
\hline Variables & Incent & $D A$ & Chairman & $\begin{array}{l}\text { Indep } \\
\text { director }\end{array}$ & Size & Accfirm & Audit & Leverage & BtoM & Var-Indyld \\
\hline Incent & 1 & & & & & & & & & \\
\hline$D A$ & -0.0059 & 1 & & & & & & & & \\
\hline Chairman & $0.0867^{* * *}$ & $0.0346^{* *}$ & 1 & & & & & & & \\
\hline Indep_Director & 0.0113 & -0.0008 & $0.0741^{* * *}$ & 1 & & & & & & \\
\hline Size & $0.0697^{* * *}$ & $-0.1105^{* * *}$ & $-0.1136^{* * *}$ & $0.0282^{*}$ & 1 & & & & & \\
\hline Accfirm & -0.0216 & $-0.0333^{* *}$ & $-0.0523^{* * *}$ & $0.0361^{* *}$ & $0.3292^{* * *}$ & 1 & & & & \\
\hline Audit & $0.0673^{* * *}$ & $-0.0346^{* *}$ & 0.0114 & $-0.0264 *$ & $0.1074^{* * *}$ & $0.0296^{* *}$ & 1 & & & \\
\hline Leverage & $-0.0503^{* * *}$ & $0.1026^{* * *}$ & $-0.0413^{* * *}$ & 0.0144 & $0.2995^{* * *}$ & 0.0218 & $-0.2033^{* * *}$ & 1 & & \\
\hline BtoM & $-0.0282^{*}$ & 0.0153 & $-0.0871^{* * *}$ & $0.0248^{*}$ & $0.6111^{* * *}$ & $0.1232^{* * *}$ & $0.034^{* *}$ & $0.4658^{* * *}$ & 1 & \\
\hline Var-Indyld & -0.0010 & $0.0577^{* * *}$ & $-0.0278^{*}$ & 0.0138 & $-0.0471^{* * *}$ & $0.0249^{*}$ & 0.0016 & $0.0336^{* *}$ & $-0.0344^{* *}$ & 1 \\
\hline
\end{tabular}

${ }^{* * *}$ Means the significance level $=0.01 ;{ }^{* *}$ Means the significance level $=0.05 ;{ }^{*}$ Means the significance level $=0.1$.

Table 3. Empirical analysis of regression model.

\begin{tabular}{|c|c|c|c|}
\hline \multirow{2}{*}{ Dependent } & Model 1 & Model 2 & Model 3 \\
\hline & $D A$ & Info & Info \\
\hline (Constant) & $0.2027^{* * *}(0.0000)$ & $-0.8054^{* * *}(0.0000)$ & $-0.7986^{* * *}(0.0000)$ \\
\hline Incent & $0.0098^{*}(0.0521)$ & $0.0464^{* *}(0.0276)$ & $0.0465^{* *}(0.0283)$ \\
\hline$D A$ & & & $-0.0135(0.6666)$ \\
\hline Chairman & $0.0017(0.1323)$ & & \\
\hline Indep_Director & $-0.0313^{*}(0.0514)$ & & \\
\hline Size & $-0.0191^{* * *}(0.0000)$ & $0.0679^{* * *}(0.0000)$ & $0.0668^{* * *}(0.0000)$ \\
\hline Accfirm & $-0.0018(0.2546)$ & & \\
\hline Audit & $-0.0125^{* * *}(0.0009)$ & & \\
\hline Leverage & & $-0.2439^{* * *}(0.0000)$ & $-0.2424^{* * *}(0.0000)$ \\
\hline BtoM & & $0.0811^{* * *}(0.0000)$ & $0.0811^{* * *}(0.0000)$ \\
\hline Var-Indyld & & $278.5099^{* * *}(0.0000)$ & $278.5324^{* * *}(0.0000)$ \\
\hline Industry & Control & Control & Control \\
\hline Adjusted $R^{2}$ & 0.0869 & 0.2032 & 0.2024 \\
\hline F-Value & $21.1779^{* * *}$ & $57.0490^{* * *}$ & $54.1153^{* * *}$ \\
\hline
\end{tabular}

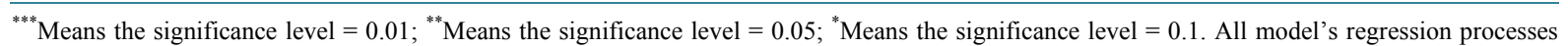
have been corrected for heteroscedasticity by deploying white heteroscedasticity correcting method.

informativeness of stock price using the data of 893 A-Share companies from 2010 to 2014. We reach following conclusions:

- Equities incentive which is currently frequently used in Chinese listed companies will increase the synchronization of individual company's stock yield and market yield as well as industry, making the stock price contain less individual company's information, which may reduce the efficiency of security market and mislead investors in judging a company's actual performance.

- Equities incentive for management tends to stimulate management to deploy earnings management, but this relation is relatively weak in current security market, which may indicate an improvement in Chinese security market regulations and supervision. 
- Earnings management that results from deploying equities incentive has no significant effect on informativeness of stock price. The effects of equities incentive through other factors have more intense influences on informativeness. Therefore, earnings management may not be an important factor to worry about when a company is considering issuing equities incentive to management; shareholders and stakeholders should pay more attention to other factors, such as information disclosure and management's interest of relationship with other interested parties, if they decide to deploy equities incentive.

In summary, issuing equities incentive tends to degrade the informativeness of stock price, but earnings management is not an important factor that results in the negative relationship between equities incentive and informativeness of stock price.

This article also has its limitations. Roll's method for measuring informativeness of stock price has come out for a very long time, whether it still suits the security market condition now remains to be verified. Besides, this article hasn't investigated the shareholder character's effect on management behaviors, such as dividing the sample companies into state-owned and privately-owned. Follow-up studies can further take the effect of shareholder into consideration and improve the reliability of the conclusion.

\section{References}

[1] Roll, R. (1988) The Stochastic Dependence of Security Price Changes and Transaction Volumes: Implications for the Mixture-of-Distributions Hypothesis. The Journal of Finance, 43, 541-566. http://dx.doi.org/10.1111/j.1540-6261.1988.tb04591.x

[2] Wurgler, J. (2000) Financial Markets and the Allocation of Capital. Journal of Financial Economics, 58, 187-214. http://dx.doi.org/10.1016/S0304-405X(00)00070-2

[3] Chen, Q., Goldstein, I. and Jiang, W. (2007) Price Informativeness and Investment Sensitivity to Stock Price. Review of Financial Studies, 20, 619-650. http://dx.doi.org/10.1093/rfs/hhl024

[4] Jones, J. (1991) Earnings Management during Import Relief Investigation. Journal of Accounting Research, 29, 193228. http://dx.doi.org/10.2307/2491047

[5] Gao, P.J. and Shrieves, R.E. (2002) Earnings Management and Executive Compensation: A Case of Overdose of Option and Underdose of Salary. University of Tennessee, Working Paper.

[6] Wei, Y. (2004) Executive Stock Option Exercises, Insider Information and Earnings Management. University of Utah, Unpublished Working Paper.

[7] Armstrong, C.S., Jagolinzer, A.D. and Larcker, D.F. (2010) Chief Executive Officer Equity Incentives and Accounting Irregularities. Journal of Accounting Research, 48, 225-271. http://dx.doi.org/10.1111/j.1475-679X.2009.00361.x

[8] Erickson, M., Michelle, H. and Edward, L.M. (2006) Is There a Link between Executive Equity Incentives and Accounting Fraud? Journal of Accounting Research, 44, 113-143. http://dx.doi.org/10.1111/j.1475-679X.2006.00194.X

[9] Zhao, X., Shi, Y.L. and Zhang, Z.Y. (2008) An Empirical Study on Earnings Management Induced by Share Incentives for Executives. Journal of Xidian University (Social Science Edition), 3, 23-28.

[10] Lin, D.P. (2011) The Corporate Governance Effect of Managerial Stock Incentives: An Empirical Analysis Based on Earnings Management and Firm Performance. Jinan University, Guangzhou.

[11] Chen, Q.L. (2008) Equity Incentives, Earnings Manipulation and State-Owned Shareholding Reduction. Journal of Sun Yat-sen University (Social Science Edition), 1, 149-155.

[12] Tian, C.Z. and Wu, X.C. (2010) The Research of Institutional Investors and Firm Value: Evidence from the Tender Offer of Listed Companies. Nankai Business Review, 4, 28-34.

[13] Yuan, Z.Z. and Qi, X.F. (2009) Institutional Environment, Corporate Governance and Stock Price Informativeness. Journal of Management Sciences, 1, 17-29.

[14] Zhu, Y.Q. (2014) Audit Quality, Management Ownership and Stock Price Synchronicity. Southwest Jiaotong University, Chengdu.

[15] Zhang, Y.M. (2011) Product Market Power, Corporate Governance and the Information Content of Stock Price. South China Journal of Economics, 12, 26-40.

[16] Lu, Y. and Shen, X.L. (2011) Earnings Management and Informativeness of Stock Price-Based on the Empirical Study of Chinese Security Market. Journal of Financial Research, 12, 131-146.

[17] Liang, Q.X. (2012) Earnings Management, New Accounting Standards and Stock Price Synchronicity. The 18th Chinese Finance Annual Meeting Proceedings of Chinese Accounting Association Professional Committee of Financial Management, Nanning, November 2012, 1-19. 
[18] Xia, F. (2012) The Synchronization of Earnings Management, Investors Emotion and Stock Price. Securities Market Herald, 8, 49-56.

[19] Healy, P.M. and Wahlen, J.M. (1999) A Review of the Earnings Management Literature and Its Implications for Standard Setting. Accounting Horizons, 13, 365-383. http://dx.doi.org/10.2308/acch.1999.13.4.365 